OPEN ACCESS

Edited by:

Satyanarayan R. S. Dev, Florida Agricultural and Mechanical

University, United States

Reviewed by:

Akinbode A. Adedeji,

University of Kentucky, United States

Tao Feng,

Shanghai Institute of Technology, China

*Correspondence: Jyoti Ranjan Rout routjiaiph.ac.in

Specialty section: This article was submitted to Nutrition and Food Science Technology,

a section of the journal Frontiers in Nutrition

Received: 05 May 2020 Accepted: 22 June 2020

Published: 06 August 2020

Citation:

Satapathy S, Rout JR, Kerry RG,

Thatoi H and Sahoo SL (2020) Biochemical Prospects of Various Microbial Pectinase and Pectin: An Approachable Concept in Pharmaceutical Bioprocessing. Front. Nutr. 7:117.

doi: 10.3389/fnut.2020.00117

\section{Biochemical Prospects of Various Microbial Pectinase and Pectin: An Approachable Concept in Pharmaceutical Bioprocessing}

\author{
Sonali Satapathy ${ }^{1}$, Jyoti Ranjan Rout ${ }^{2 *}$, Rout George Kerry ${ }^{3}$, Hrudayanath Thatoi $^{4}$ and \\ Santi Lata Sahoo ${ }^{1}$ \\ ${ }^{1}$ Microbiology Research Laboratory, Post Graduate Department of Botany, Utkal University, Bhubaneswar, India, ${ }^{2}$ School of \\ Biological Sciences, AIPH University, Bhubaneswar, India, ${ }^{3}$ Post Graduate Department of Biotechnology, Utkal University, \\ Bhubaneswar, India, ${ }^{4}$ Department of Biotechnology, North Orissa University, Baripada, India
}

Both pectin and pectinase are vitally imperative biomolecules in the biotechnological sector. These molecules are a feasible non-toxic contrivance of nature with extensive applicative perception. Understanding pectic substances and their structure, unique depolymerization, and biochemical properties such as a catalytic mechanism and the strong interrelationship among these molecules could immensely enhance their applicability in industries. For instance, gaining knowledge with respect to the versatile molecular heterogeneity of the compounds could be considered as the center of concern to resolve the industrial issues from multiple aspects. In the present review, an effort has been made to orchestrate the fundamental information related to structure, depolymerization characteristics, and classification of pectin as well as the types and biochemical properties of pectinase. Furthermore, various production methods related to the optimization of the product and its significant contribution to the pharmaceutical industry (either pectinase or derived pectic substances) are described in this article.

\section{Keywords: biochemical properties, depolymerization, pectic substances, pectinase, pharmaceutical application,} production method

\section{INTRODUCTION}

Over the past centuries, there has been a notable increase in the application of enzymes in various sectors of industry. This is because the enzymes could be used as a substitute for some toxic chemicals that were previously involved in food processing. On the other hand, the biotechnological approaches involving the identification of microbial enzymes, mechanisms of action, and scaled-up production are a critical challenge to the researchers $(1,2)$. Protein engineering, in addition to recombinant processes, is an approachable alternative to engineer recombinant enzymes that enhance the rate of action in various aspects. There have been number of microbe-borne enzymes (amylase, cellulase, glucosidases, invertase, keratinases, lactase, ligninase, lipase, penicillinase, protease, xylanase, etc.) developed and commercially popularized due to their highly significant action as well as economic feasibility $(3,4)$. 
The enzyme pectinase has engrossed interest worldwide as a biological catalyst in various industrial processes. This enzyme breaks down pectin commonly found in the plant cell wall and, hence, is well-known for the commercial preparation of clear fruit juice, liquefaction and saccharification of plant biomass, paper making, as well as coffee and tea fermentation (5). Pectin is a structural acidic heteropolysaccharide rich in galacturonic acid with carboxyl groups esterified with the methanol. The acidic heteropolysaccharide is a major component in cereals, vegetables, and fruits. Pectic substances are high in molecular weight, biocompatible, non-toxic, anionic natural polysaccharides, and foremost constituents of the middle lamella and primary cell wall of plants (6). Pectinase possesses a complicated enzymatic system responsible for the degradation of pectic substances like pectinic acids, propectins, pectins, and pectic acids (7). According to the enzymatic nomenclature system, pectinase hydrolyses the pectin polymer more efficiently than other pectinase groups of enzymes. Moreover, their actions are also more specific as they belong to a heterogeneous group of enzymes named as polygalcturonase (PG), pectinesterase (PE), and pectin lyase (PL) (8). The primary chain of pectin partly comprises methyl esterified 1,4D-galacturonan and a demethylated form of pectin which is also known as pectic acid (pectate) or polygalacturonic acid. Basically, the pectinase acts by splitting glycosidic linkages and converts the polygalacturonic acid into monogalacturonic acid (9).

Microorganisms and plants have a proven record of being the major sources of the pectinase enzyme. However, because of technical and commercial viability, pectinase generation from microbial sources is becoming a primary area of research interest $(9,10)$. Naturally, this enzyme plays a significant role in the metabolic activities of almost all living organisms right from the complex to very simple ones such as plants, animals, fungi, bacteria, and viruses (10). However, researchers are now focused on how to improve its efficacy with respect to various aspects by involving various biotechnological tools. Furthermore, scientists are also emphasizing enabling or modifying pectinase so that it could be of application in different bioprocessing industrial sectors $(11,12)$. Pectinolytic enzymes are employed in many industrial applications but are mainly utilized in food industries in specific operations such as the clarification of fruit juices and wines and the extraction of vegetable oils. They are also widely used in the processing and elimination of pectin, which is crucial in coffee and tea processing, macerating of plants and vegetable tissue, degumming of plant fibers, treatment of wastewater, bleaching of paper, and as an additive in the poultry feeding and textile industries $(13,14)$. The benefaction of pectinase is also distributed toward maintaining intestinal microbiota homeostatic balance by improving nutritional prebiotic values by processing plant-based foods (15). Enzymatic preparations of pectin are also implemented in various pharma-based industries for the development of low-methoxy pectin that is beneficial for diabetic patients $(14,16)$. Purified forms of pectinase, which are commercially isolated from different fungal species, have a great role in plant protoplast culture studies as they help to generate good yields of viable protoplast when treated with cellulose (17). However, like other enzymes, this one is also more activated during its commercial production at 30 to $50^{\circ} \mathrm{C}$ and a $\mathrm{pH}$ of 4.5 to 8.5 , but the effectiveness is more specific to the source of particular microorganisms and other environmental factors (10).

Hence, due to market and economic demand, the detailed information about the structure, depolymerization properties, and classification of pectic substances as well as the types and biochemical properties of pectinase are collected from literature search and presented in the present review. In addition, the review also presents an overall idea about the different production methods of pectinase and pharmaceutical applications of both pectin and pectinolytic enzyme. Thus, it is hoped that the review article may support the building of conceptual knowledge on the protease enzyme and its substrate.

\section{PRODUCTION METHODS OF SELECTED PECTINASE FROM MICROORGANISMS}

Naturally occurring pectinases are basically found in either plants or microorganisms, but their isolation and commercial production from microbial sources will meet the industrial needs through a large-scale production involving the fermentation process. The initial isolation and identification of selective microbes, screening of selective media, and production process either via flask culture or scale-up culture (fermentation process) are the critical tasks to optimize the individual enzymes. Moreover, the standardization of the substrate concentration optimization with respect to environmental factors is also a critical factor to postulate an effective function of pectinolytic enzymes. The significant contribution of these enzymes has drawn considerable attention from different biotechnologists worldwide to enhance their potentiality by adapting several recombinant strategies $(18,19)$. The commercialized pectinase enzymes are produced by either submerged fermentation ( $\mathrm{SmF}$ ) or solid-state fermentation (SSF) that varies in the use of selected fungus or bacteria (20-22). The SmF technique has been adopted since 1940s when the microorganisms were cultivated on liquid broth with constant agitation for the largescale production of antibiotics and later widely applied in various industries for the production of a huge assortment of microbial metabolites $(23,24)$. On the other hand, the SSF is also applicable in various sectors for enzyme production where microorganisms are cultured on solid materials which are ecofriendly, cost-effective, and highly productive and have high biomass yield, dwindled proteolytic impact, higher resistance to catabolic repression, better product quality, etc. $(25,26)$. The selection or adaptation of a specific technique as well as a suitable medium depends on selected microorganisms, including some surrounding environmental factors for the optimization of pectinase production. Some significant contributions relating to selectable substrate-containing media and their production methods are listed in Table $\mathbf{1 .}$ 
TABLE 1 | List of various screening or production media and production processes for the discovery of specific pectinase enzymes.

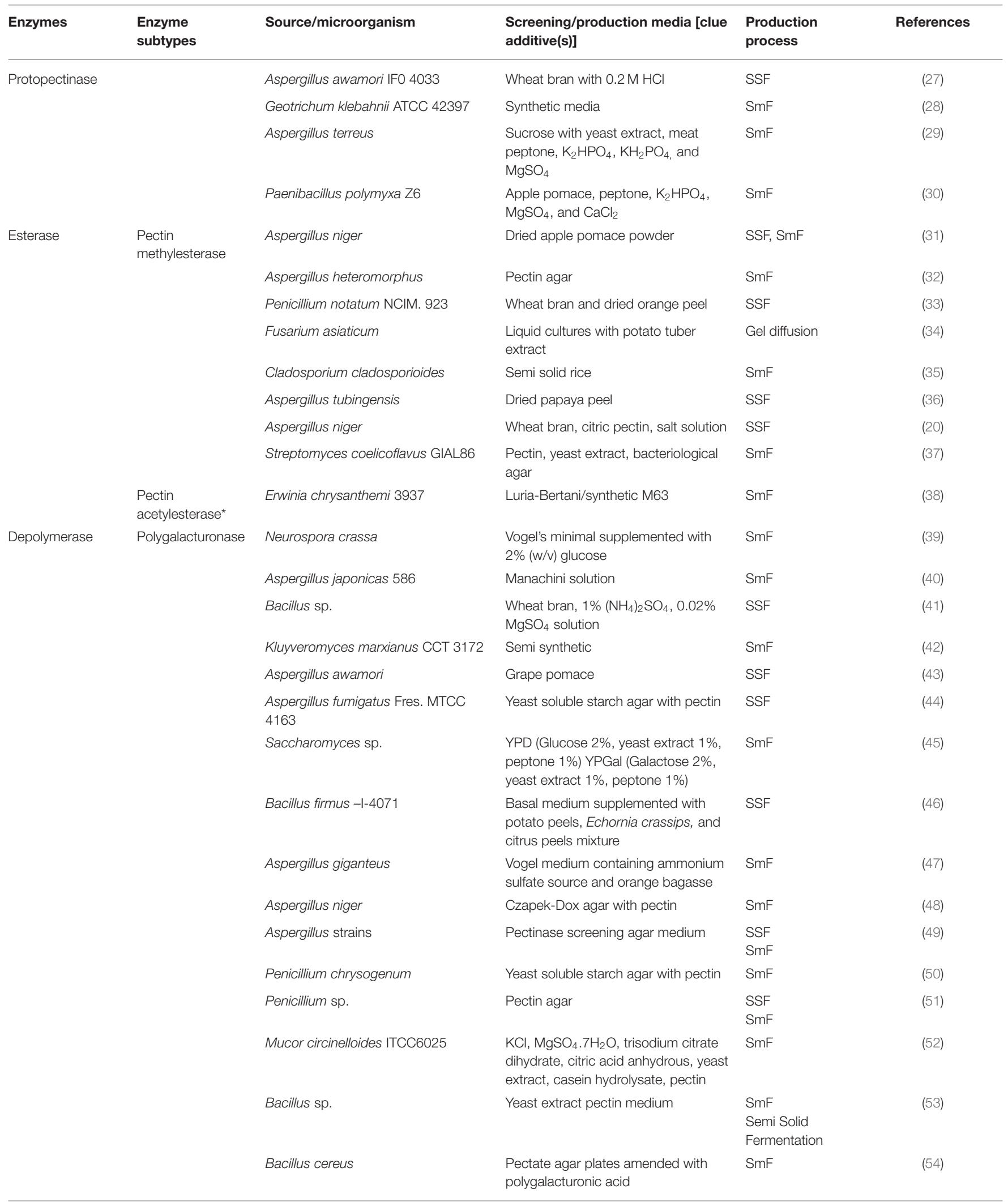


TABLE 1 | Continued

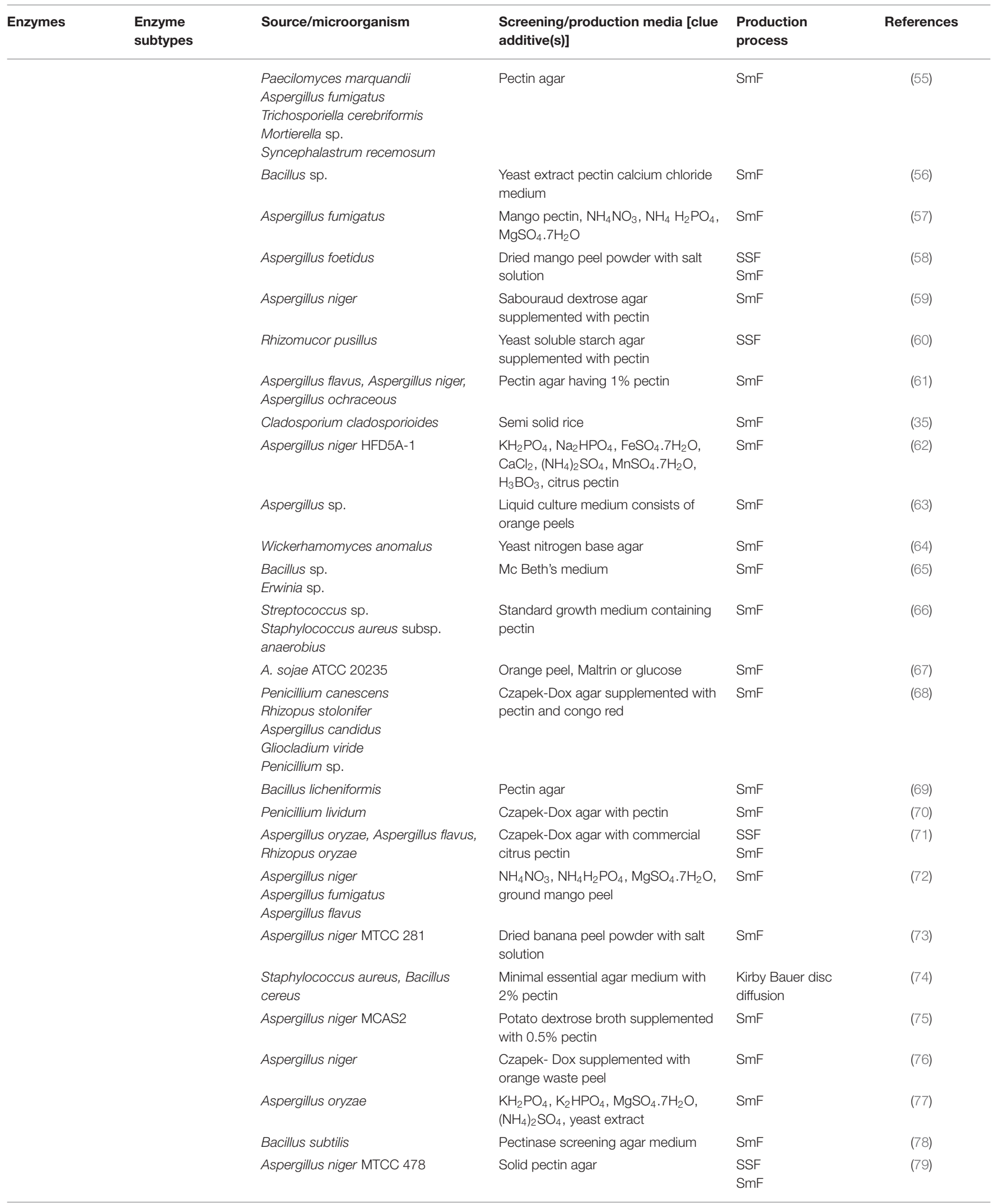


TABLE 1 | Continued

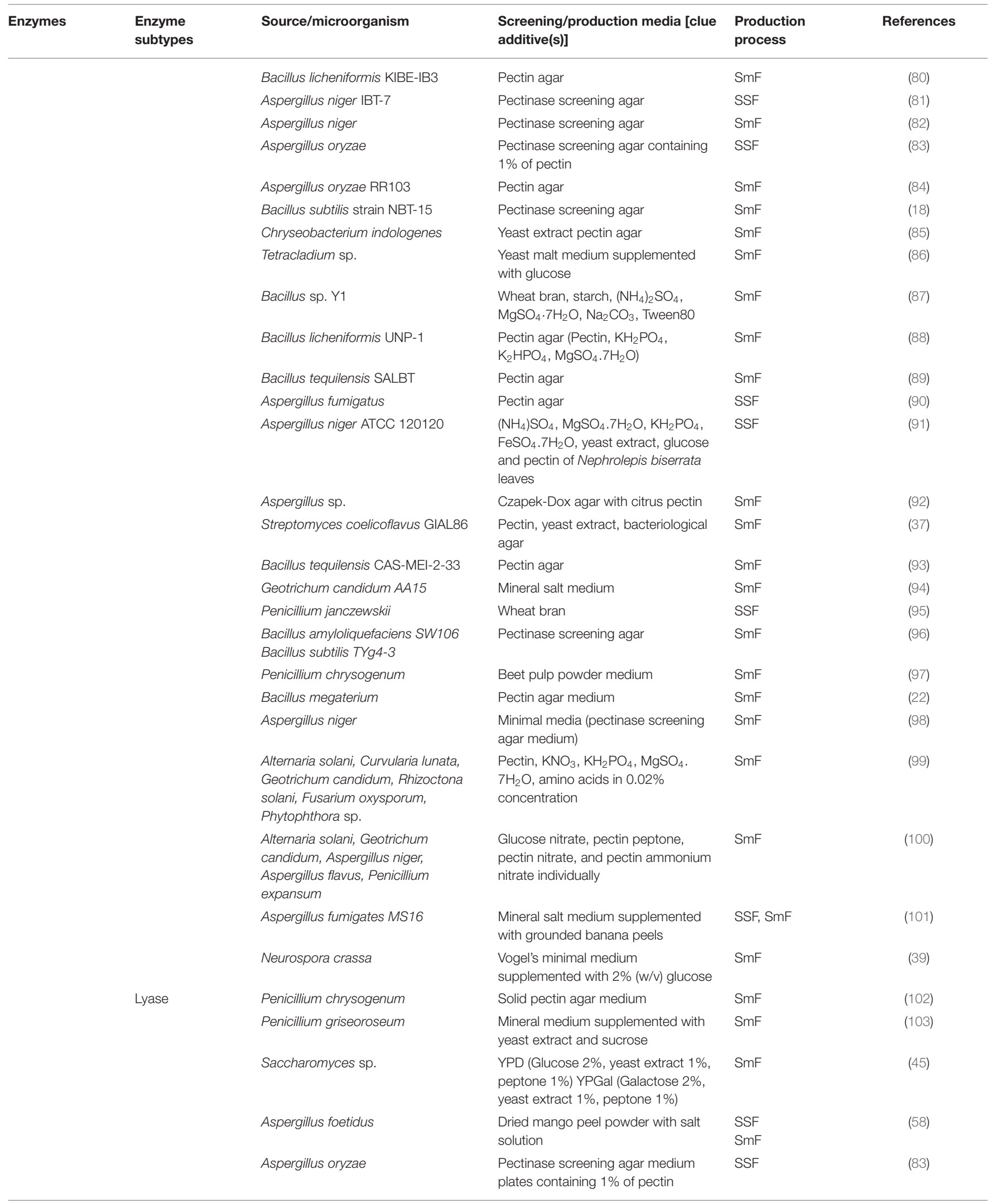


TABLE 1 | Continued

\begin{tabular}{|c|c|c|c|c|c|}
\hline Enzymes & $\begin{array}{l}\text { Enzyme } \\
\text { subtypes }\end{array}$ & Source/microorganism & $\begin{array}{l}\text { Screening/production media [clue } \\
\text { additive(s)] }\end{array}$ & $\begin{array}{l}\text { Production } \\
\text { process }\end{array}$ & References \\
\hline & & Aspergillus niger & Wheat bran, citric pectin, salt solution & SSF & (20) \\
\hline & & Streptomyces coelicoflavus GIAL86 & $\begin{array}{l}\text { Pectin, yeast extract, bacteriological } \\
\text { agar }\end{array}$ & SmF & (37) \\
\hline & & Escherichia coli BL21 & Glycine added medium & $\mathrm{SmF}$ & (105) \\
\hline
\end{tabular}

\section{CLASSIFICATION AND BIOCHEMICAL PROPERTIES OF PECTINOLYTIC ENZYMES}

Pectic enzymes are also known as pectinases or pectinolytic enzymes, which have the capacity to hydrolyze the various complex pectic substances. These enzymes are classified into three major types including protopectinases, esterase, and depolymerases, on the basis of their mechanism of action on pectin molecules and preferred substrates. Protopectinases is a group of enzymes that are responsible for the hydrolysis of the substrate protopectin and converting it to soluble pectin. Esterase is a class of enzymes that removes methoxyl and acetyl esters from pectin resulting in the formation of polygalacturonic acid. Depolymerases also contribute toward the breakdown of peptic substances by the cleaving of $\alpha$ - $(1 \rightarrow 4)$-glycosidic bonds in DGalA units either by hydrolysis or by trans-elimination $(13,106)$. However, the above system of classification is outdated, and most recently, the pectic enzymes are broadly separated as per the nature of action mechanism, primary substrate, and products that are narrated below and also schematically outlined in Figure $\mathbf{1}$.

\section{Protopectinase}

Protopectinases (PPases) are also synonymous to pectinosinases, which interact with insoluble protopectin in the presence of water and converts it into simple and soluble pectin. The term was initially used around 1927 and recently popularized due to its importance in various sectors of industry like the production of pectin, single-cell protein, and protoplast $(108,109)$. More specifically, these enzymes could catalyze the protopectin by reacting at sites having three or more non-methylated GalA molecules and hydrolyzing the glycosidic bond $(106,110)$. Based on the catalytic action, these are categorized as type A PPase, which reacts with the polygalacturonic acid region or inner site of insoluble protopectin, whereas type B PPase responds at the site of polysaccharide chains or outside of the insoluble protopectin, which links the polygalacturonic acid chain and the cell wall components (110).

Type A PPase has also been reported in the culture filtrate of many yeasts like fungi such as Kluyveromyces fragilis IFO 0288, Galactomyces reessi, and Trichosporon penicillatum SNO 3 , referred to as PPase-F, $-\mathrm{L}$, and $-\mathrm{S}$, respectively. The biological properties of all the three types of PPases are alike, possessing the same molecular weight of about $30 \mathrm{kDa}$. Further, it was found that all three types of enzymes were more optimum at $\mathrm{pH}$ 5.0. Among the three A types of PPases, only PPase-F is an acidic protein, while others are basic in properties. These enzymes play a vital role in the hydrolysis of polygalacturonic acid and also responsible for a decrease in viscosity with an enhanced rate of reduction in a certain reaction medium containing polygalacturonic acid. Similarly, PPase- $\mathrm{N}$ and - $\mathrm{R}$ were also identified from Bacillus subtilis IFO 3134 with 43 and $35 \mathrm{kDa}$ protein, respectively, which help in transelimination reaction by splitting the glycosidic linkages at the region of protopectin. The enzymes were highly active at the same $\mathrm{pH}(8.0)$ and temperature $\left(60^{\circ} \mathrm{C}\right)(111,112)$. Type B PPases have been isolated from the pure culture of B. subtilis IFO 3134 and Trametes sunginea, which are also named as PPase-C and - $\mathrm{T}$, respectively. In this case, different molecular weights of proteins like 30 (PPase-C) and $55 \mathrm{kDa}$ (PPase-T) were detected along with different isoelectric points (PPas-C: 9.0; PPase-T: 8.1). As reported, these types of enzymes are abundantly found in agro-products like lemon, orange, hassaku, apple, burdock, carrot, radish, sugar beet, etc. where they particularly act on protopectin $(109,113)$.

\section{Esterase}

Pectinesterases are the enzymes which help to separate methoxyl and acetyl residues from pectin, resulting in the formation of polygalacturonic acid. Pectinesterases from fungal sources work in a multi-chain mechanism by eliminating the methyl groups but in an arbitrary manner, whereas the pectinesterases from plant sources work in a single-chain mechanism, by targeting either the non-reducing terminal or that next to a free carboxyl group and then advancing in a linear fashion $(114,115)$. Pectinesterases are classified into two types as per the targeting functional groups, which are named as pectin methylesterase or pectinesterase and pectin acetylesterase. Pectin methylesterase works in single-chain mechanism by dividing the methyl ester group of pectin and thereby freeing methanol and converting pectin into pectate; but in this action, the length of the pectic chains are not reduced (116). Variably, the enzyme pectin acetylesterase catalyzes the hydrolysis of acetyl ester residues of pectin, resulting in pectic acid and acetate formation (110). 


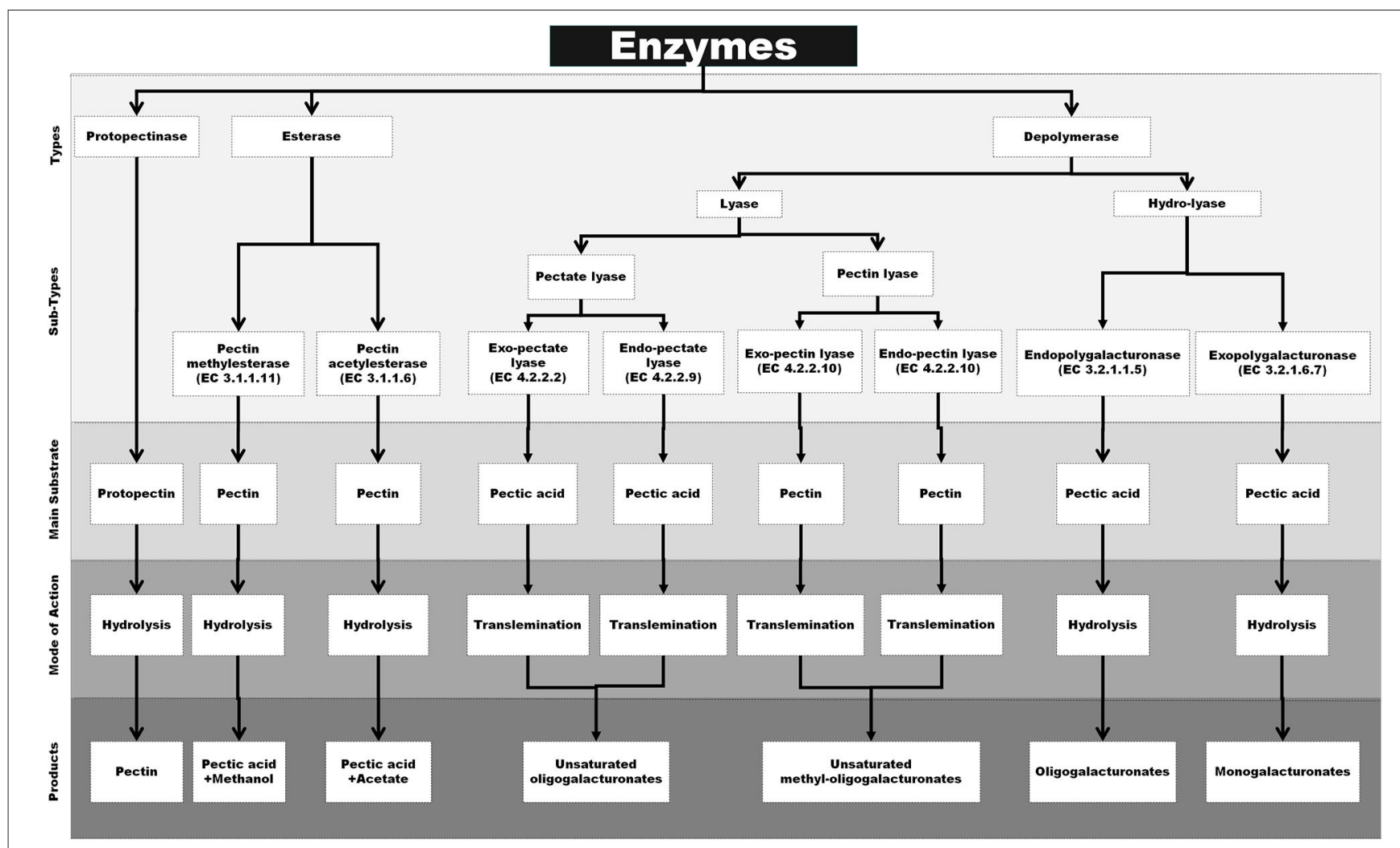

FIGURE 1 | Schematical representation of specific substrate, mode of action and end products of various pectinase [Inspired from Garg and Singh (107)].

The screening and production of this category of enzymes have been done in maximum from microbiological sources as compared to plants and animals $(112,117)$. The rate of enzymatic action of pectinesterase on the viscosity of a solution containing pectin is almost negligible without the divalent cations like calcium $\left(\mathrm{Ca}^{2+}\right)$, barium $\left(\mathrm{Ba}^{2+}\right)$, and strontium $\left(\mathrm{Sr}^{2+}\right)$. However, the maximum and effective involvement of $\mathrm{Ca}^{2+}$ ions is reported as either small- or large-scale preparations (118). Basically, some of the purified pectinesterases are targeted to the reducing end, whereas others are acting against the non-reducing end of the pectin. As per molecular characterization, most of the enzymes ranging from 22 to $90 \mathrm{kDa}$ indicate a diversification of protein confirmations. However, these variations are organismspecific. Their work efficiency also varies with different $\mathrm{pH}$ levels and temperatures and ranges in $\mathrm{pH}$ from 5 to 11 and temperature from 40 to $70^{\circ} \mathrm{C}$. However, it was depicted that fungal pectinesterases have a lower $\mathrm{pH}$ level for the optimization of products as compared to that of bacterial pectinesterases (13). The separation of various unique isoenzymes of pectin methylesterases have been achieved and characterized from different sources with respect to targeted functional groups $(116,119)$. The structural characterization of two pectin methylesterases such as PmeA and PmeB are well-studied from Erwinia chrysanthemi (120) and Erwinia chrysanthemi 3937 (121) and functionally found to be extracellular and outer membrane acting enzymes, respectively.

\section{Depolymerase}

\section{Polygalacturonase}

Among all pectinolytic enzymes, polygalacturonases (PGases) are the most studied and industrially applied enzymes due to their depolymerization specificity through the hydrolysis process. These enzymes are specifically interactive through hydrolysis and split the glycosidic linkage in the presence of water molecules across the oxygen bridge. Polygalacturonase loses its structural confirmation when it reacts with pectin, which may occur because of the target molecules of polygalacturonases that have free carboxylic groups. During interaction with substrates, the viscosity of the solution reduces to a greater extent with an increase of reducing end groups (112). Polygalacturonases are classified into three types (exopolygalacturonase, endopolygalacturonase, and rhamnopolygalacturonase) depending on their pattern of action. Exopolygalacturonase targets the terminal groups of the pectic molecule, which results in gradual lessening of chain length, whereas endopolygalacturonase attacks arbitrarily on all the chain links, which results in faster and more incisive consequences. However, rhamnopolygalacturonase catalyzes haphazardly within or at the non-reducing terminals of rhamnogalacturonan core chains $(122,123)$.

There are several important biochemical properties and modes of actions of polygalacturonases obtained from various microbial sources. Most of the polygalacturonase enzymes 
stimulate the rate of hydrolysis at an ideal $\mathrm{pH}$ ranging from 3.5 to 5.5 with a suitable temperature that ranges from 30 to $50^{\circ} \mathrm{C}$. Several findings relating to various biochemical properties like molecular weight, $\mathrm{pH}$, temperature, isoenzyme, isoelectric point, etc. are well-reported with respect to endopolygalacturonase in various bacterial and fungal species as compared to exopolygalacturonase and rhamnopolygalacturonase. As reported, almost all endopolygalacturonase as well as exopolygalacturonase enzymes are synthesized in acidic environmental conditions, whereas, some exopolygalacturonases are produced at high basic conditions (about $\mathrm{pH} 11.0$ ) and by particular species including Bacillus licheniformis, Bacillus sp KSM-P410 and Fusarium oxysporum (13). Regarding rhamnopolygalacturonases, it was stated that the enzymes are more stable and efficiently work at $\mathrm{pH} 4.0$ and a temperature of $50^{\circ} \mathrm{C}$ (124). At an average molecular weight of 38-65 $\mathrm{kDa}$, the enzymes (for both exopolygalacturonases and endopolygalacturonases) are separated from various microbial sources (13). However, at a high molecular weight of $496 \mathrm{kDa}$, enzymes were also isolated from Kluyveromyces marxianus (125). Similarly, the protein having a molecular weight of $66 \mathrm{kDa}$ is electrophoresed from the rhamnopolygalacturonase (124).

\section{Lyase}

Lyases (also known as transeliminases) act by performing the trans-eliminative breakdown of pectate or pectinate polymers. The lyases typically split the glycosidic linkages at 4th carbon followed by the removal of a hydrogen atom from 5th carbon that results in an unsaturated product. On the basis of the substrates acted upon, lyases are classified into two major types, i.e., polygalacturonate lyase and polymethylgalacturonate lyase. However, they are further subdivided into five subtypes, namely, endo-polygalacturonate lyase, exo-polygalacturonate lyase, endopolymethylgalacturonate lyase, exo-polymethylgalacturonate lyase, and oligo-D-galactosiduronate lyase as per their pattern of action (115). Polygalacturonate lyases (or pectate lyases) are further divided into two types depending on the pattern of action, i.e., endo-polygalacturonate lyases that work on the substrate in an unsystematic fashion, whereas exo-polygalacturonate lyases target the substrates from non-reducing terminal of pectic acid. In the same way, polymethylgalacturonate lyases (or pectin lyases) are also divided into two categories such as endo-polymethylgalacturonate lyases (that randomly act on the substrate pectin by cleaving $\alpha$-1,4-glycosidic linkages and producing unsaturated methyloligogalacturonates) and exo-polymethylgalacturonate lyases (that degrade pectin by trans-eliminative cleavage but stepwise and produce unsaturated methylmonogalacturonates) (126, 127). The oligo-D-galactosiduronate lyases actively participate in the transelimination reaction at the terminal position of unsaturated digalacturonate that is initially produced by the action of pectate lyases and converted into unsaturated monogalacturonates $(128,129)$.

Microorganisms are the good sources for isolation of pectin lyases, but the biochemical properties of each isolated lyase are different. Polygalacturonate lyases or pectate lyases exclusively require $\mathrm{Ca}^{2+}$ ions for its activation. However, ions like $\mathrm{Co}^{2+}, \mathrm{Mn}^{2+}$, and $\mathrm{Ni}^{2+}$ are needed for activation of some cytoplasmic or intracellular lyases (126). It is reported that the polymethylgalacturonate lyases or pectin lyases do not require any metal ions for their activation, but arginine residues are found at the $\mathrm{Ca}^{2+}$ ion position as observed in the case of pectate lyases (130). Overall, both types of enzymes are efficient for working in an alkaline $\mathrm{pH}$ range of 7.5-10.0 and a temperature between 40 and $50^{\circ} \mathrm{C}$. The molecular weights of lyases are ranging from 22 to $90 \mathrm{kDa}$, whereas the molecular weights of polymethylgalacturonate lyases were found to be 89 and $90 \mathrm{kDa}$ in Aureobasidium pullulans LV-10 and Pichia pinus, respectively. For polygalacturonate lyases, the molecular weights of 55 and $74 \mathrm{kDa}$ of proteins were reported in Yersinia enterocolitica and Bacteroides thetaiotaomicron, respectively. The isoelectric point of some lyases range from 5.2 to 10.7 ; however, others still need to be explored (13).

\section{STRUCTURE AND DEPOLYMERIZATION OF PECTIN}

The naturally occurring pectins or pectic substances are chiefly composed of galacturonic acid (GalA)-rich polysaccharides in the form of covalently-linked structural motifs that include homogalacturonan (HG), xylogalacturonan (XGA), rhamnogalacturonan I (RG-I), and rhamnogalacturonan II (RG-II). However, the occurrences of HG are maximum (about $65 \%)$ in pectin $(131,132)$. About hundred GalA moieties are linked by $\alpha$-D-1,4- bonds and form HG that is further modifiable by the process of methyl-esterification at C-6, or acetyl groups at $\mathrm{O}-2$ and O-3. Similarly, XGA is an HG backbone, where $25-75 \%$ of the GalA units are substituted at C-3 with one xylose moiety and sometimes with a second xylose residue at C-4 $(114,132)$. RG-I is also a complex polymer which contributes $20-35 \%$ of pectin in recurring units of $\alpha-\mathrm{D}-\mathrm{GalA}-1$ and $2-\alpha-\mathrm{L}-$ Rha-1-4-disaccharide. Sometimes, lateral chains contain fucose and glucuronic acids available mostly to create a more complex structure. RG-II is another structural domain of pectin where the GalA residue acts as the main chain bonded by $\alpha-\mathrm{D}-1,4$ - bonds and substituted with a usual L-rhamnose or D-galactose and numerous atypical sugars and laterally conjugated by 12 different sugar molecules. Moreover, the pectin matrix properties are complicated due to the interaction of the structural domains of pectin between themselves and with other ionized organic and inorganic compounds (131-133).

Depolymerization of complex pectin and subsequent conversion into simpler forms, i.e., pectic oligosaccharides, is the center of attraction because these molecules are very large but less complex and heterogeneous in comparison to their parent compounds. Furthermore, the oligosaccharides are exploited for many vital applications like repressor of liver lipid accumulation, antioxidant and cancer cell proliferation inhibitor, anti-metastatic agent, angiogenesis inhibitor, antibacterial agent, and formation of prebiotics (134-137).

Degradation of pectin either by physical, chemical, or enzymatic methods is represented in Figure 2. Ultrasonication, high pressure treatment, radiation, and photolysis are some of 

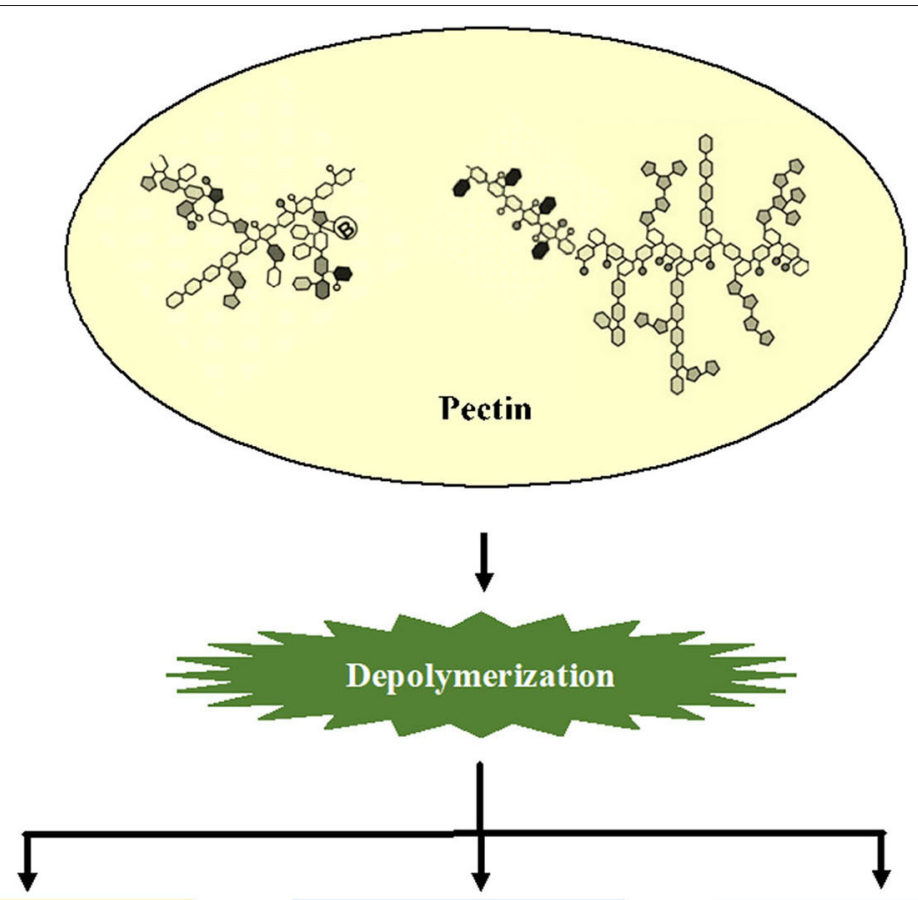

\section{Physical process}

$\rightarrow$ Dehydration

$\rightarrow$ Extrusion

$\rightarrow$ Grinding

$\rightarrow$ Heating

$\rightarrow$ High pressure treatment

$\rightarrow$ Photolysis

$\rightarrow$ Radiation

$\rightarrow$ Ultrasonication

\section{Chemical process}

$\rightarrow$ Acid hydrolysis

$\rightarrow$ Acid/ base catalysed

$\rightarrow$ Hydroxyl radicalmediated

\section{Enzymatic process}

$\rightarrow$ Acetyl esterase

$\rightarrow$ Endoarabinase

$\rightarrow$ Endogalactanase

$\rightarrow$ Endorhamnogalacturonan hydrolase

$\rightarrow$ Exoarabinase

$\rightarrow$ Exogalactanase

$\rightarrow$ Feruloyl esterase

$\rightarrow$ Pectate lyase

$\rightarrow$ Pectin lyase

$\rightarrow$ Pectin methyl esterase

$\rightarrow$ Polygalacturonase

$\rightarrow$ Ramnogalacturonan galacturonohydrolase

$\rightarrow$ Rhamnogalacturonan acetyl esterase

$\rightarrow$ Rhamnogalacturonan lyase

$\rightarrow$ Rhamnogalacturonan rhamnohydrolase

$\rightarrow \alpha$ - and $\beta$-galactosidase

$\rightarrow \alpha$-L-arabinofuranosidase and many more

FIGURE 2 | Involvement of different processes for depolymerization of various types of pectins [Inspired from Chen et al. (6)].

the physical means used in degradation. In an aqueous solution of $\mathrm{pH}$ at about 3.5, the pectins are most stable, but at lower or higher $\mathrm{pH}$, the methoxyl, acetyl, and neutral sugar groups are eliminated and the polymer backbone is cleaved. Chemically, the heteropolysaccharides can be degraded either by acid hydrolysis or base-catalyzed splitting of chains through the $\beta$-elimination 
reaction (138). The dissolution takes place at a glycosidic linkage next to an esterified GalA, as a result of which pectins with an elevated degree of methoxylation (DM) become extra susceptible to base-catalyzed reactions rather than pectin with a low DM. However, by acid hydrolysis $(\mathrm{pH}<3.0$ ), pectin hydrolyses with low DM are faster in comparison to pectin with high DM (139). Enzymatic degradation of pectin is gaining prime importance because it allows region-selective depolymerization under mild conditions. Due to the intricate molecular configuration of pectin, a wide range of enzymes are essential for the degradation of this polymer. These enzymes include polygalacturonase (PG) which degrades $\mathrm{HG}$ by hydrolyzing the glycosidic bonds and are categorized into two types, endo-PG and exo-PG (140). Lyases that include pectate lyase and pectin lyase catalyze the depolymerization of polygalacturonate and esterified pectin, respectively through $\beta$-elimination process in which a proton is removed and an unsaturated bond is formed between the C-4 and C-5 carbon atoms of the non-reducing terminal of pectin. PLYs in combination with $\mathrm{Ca}^{2+}$ degrade non-esterified pectin, and PEL in combination with $\mathrm{Arg}^{236}$ degrades methylesterified pectin (13). Some other residues of pectin such as acetyl, methyl, and feruloyl are separated by pectin methylesterase, acetyl esterase, rhamnogalacturonan acetyl esterase, and feruloyl esterase. The actions of these enzymes are imperative for the absolute degradation of pectin, as they enhance the action of other enzymes; for instance, the ability of PGs and PLYs to degrade pectin largely depends on the activity of PMEs $(141,142)$. The endorhamnogalacturonan hydrolase breaks $\alpha$-D-GalA-1,2- $\alpha$-L-Rha linkages present in RG-I by hydrolysis, and rhamnogalacturonan lyase breaks $-\alpha$-L-Rha-1,4- $\alpha$-D-GalA linkages by $\beta$-elimination reaction. Accessory enzymes like rhamnogalacturonan rhamnohydrolase and ramnogalacturonan galacturonohydrolase break down oligosaccharides from the non-reducing terminal by an exo-attack (114). There are few more enzymes which also act on the adjacent chains of RGI and RG-II such as endogalactanase, exogalactanase, $\alpha$ - and $\beta$-galactosidase, $\alpha$-L-arabinofuranosidase, endoarabinase, and exoarabinase (143).

\section{STRUCTURE AND CLASSIFICATION OF OTHER PECTIC SUBSTANCES}

Pectic substances (including pectins) are complex heteropolysaccharides that contribute to the major elements of the middle lamellae and primary cell wall of higher plants. They play very diverse roles such as maintaining the integrity and coherence of plant tissues, acting as moisturizing or gluing agents in the cell walls, and also getting involved in the plant host-pathogen interaction $(144,145)$. In general, galacturonans and rhamnogalacturonans are two major chemical components in pectic substances, where the C-6 carbon of galactate is oxidized along with arabinans and arabinogalactans. The components produced are structurally heterogeneous and colloidal polymeric in nature, containing a large backbone of anhydrogalacturonic acid units (131). The carboxyl groups present in the GalA are partially esterified by methyl residues and moderately or totally neutralized by different ions such as sodium, potassium, and ammonium. The $\alpha-1,4-\mathrm{D}$-galacturonate units act as the principal chain and link about $2-4 \%$ of L-rhamnose units which are linked $[\beta-(1 \rightarrow 2)$ and $\beta-(1 \rightarrow 4)]$ to the galacturonate units. The side chains comprise simple carbohydrates that are arabinan, galactan, arabinogalactan, xylose, or fucose but vary in their composition and length. They are linked to the central chain through their $C_{1}$ and $C_{2}$ atoms (146). As per the nature of the molecular arrangements of pectic substances, the American Chemical Society have categorized them into four major groups namely protopectin, pectic acid, pectinic acid, and pectin (Figure 3) (147). The protopectin is a water-insoluble substance that acts as a cementing agent in the cell wall and, under hydrolysis, produces either pectin or pectic acid. Similarly, pectic acid (popularly known as pectate) is a polymer of galacturonans that contains a small number of methoxyl groups. Pectinic acid is a chain of polygaluturonates that mainly contains methylated galacturonate units. Pectin a polymeric substance with at least $75 \%$ of the carboxyl groups attached to the galacturonate units and is esterified with a methyl group (148).

\section{EXTRACTION AND PURIFICATION METHODS OF PECTIN}

The growing requirements of pectin in pharmaceutical applications have accelerated the need for competent extraction processes. Commercially, these naturally occurring biomolecules can be extracted from the peels of citrus fruits by alcohol precipitation (149). In the extraction process, the recovery of pectins is vital at the industrial scale to endow with passable supply for the increasing need. At the commercial level, the hydrolyzation of proto pectin into pectin at elevated temperature using acid and subsequently precipitating by ethanol is conventionally employed (150). Limitations like lower yield, heterogenic changes in macromolecular and gelling properties, etc. have raised the urgency to find novel methods like microwave-assisted extraction, enzymatic extraction (polygalacturonase, hemicellulose, protease, cellulose, $\alpha$-amylase, alcalase, microbial mixed enzymes, etc.), supercritical water extraction, ultra-high pressure treatment, ultra-high electric field treatment, and ultrasound extraction $(151,152)$. These advanced methods exhibit a large handling capacity, lower processing time, higher purity, a mild condition, and an energy-efficient and environment-friendly way of operation (150). However, for efficient purification, proper precipitation is required, which was achieved through alcohol precipitation with washing (149). Growing, investigation proved that the purification of pectins is efficiently attained through stepwise innovative methods like ethanol precipitation, ultrafiltration in combination with diafiltration, ultrafiltration, and metal precipitation (153).

\section{PHARMACEUTICAL APPLICATION OF MICROBIAL PECTINASES AND DERIVED PECTIC SUBSTANCES}

In this modern era, various enzymes that are produced by microorganisms have been tremendously applied in different sectors of the industries that are directly or indirectly being 


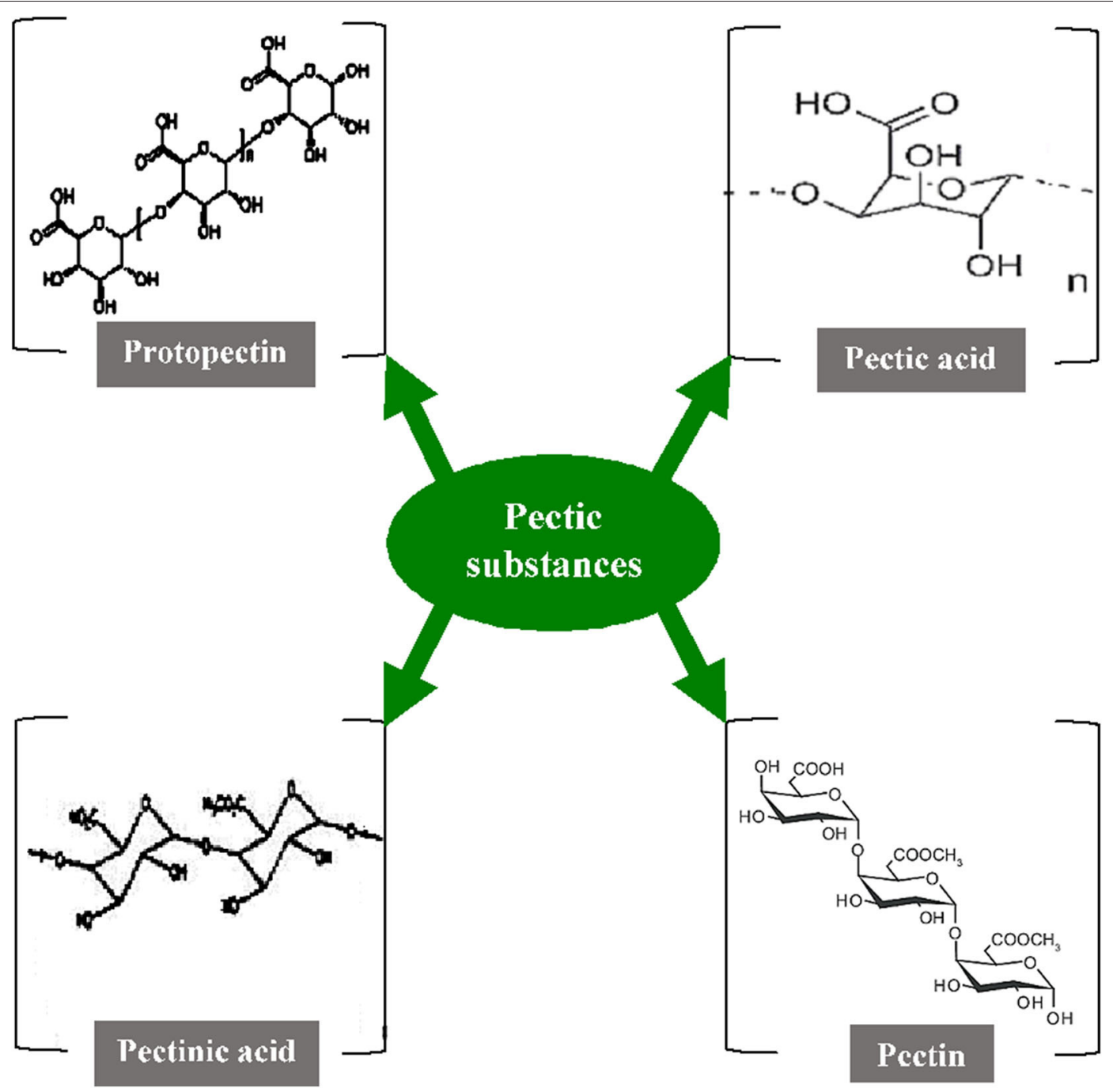

FIGURE 3 | Structure of various pectic substances [Inspired from Garg and Singh (107)].

used in day-to-day life. Enzymes are considered as the topmost biological tools due to their adjustable and specific catalytic properties owing to their increased applications in different biotechnological processes. Pectinases are one of the most significant industrial enzymes, and some of the notable contributions in pharmaceutical sectors are explained here.

\section{Dietary or Nutritive Fiber Preparation}

Humans are omnivorous and regularly consuming diversified foods that need to be properly digested in the digestive system. On the other hand, friendly microbes present in the gastrointestinal tract comprehend convolution to digest them due to the entry of foreign complex compounds in a regular fashion. For which, fermentable dietary fibers through pectinase could be helpful in modulating the internal enzymatic system for proper digestion and to improve the immune system by acting as natural prebiotics. In certain pharmaceutical products, depolymerized pectins can be directly used to increase the viscosity and volume of stool and are also prescribed against acute diarrhea and constipation. Moreover, fermented pectic substances are used in throat lozenges as a decongestant in the form of a demulcent and also used in combination with certain products for the wound-healing process. The pectic elements are used as medicated adhesives against the treatment of colostomy. Pectins, with the combination of sulfate, are used to reduce the clotting time and can be applied in place of heparin. A complex made up of degraded pectin along with iron is helpful for the treatment of iron deficiency anemia (154-156).

\section{Oil Extraction}

Essential oils from medicinal plants nowadays are widely adopted in both developed and developing countries due to their valuable medicinal properties against the treatment 
of different diseases including microbial infectious ailments, depression, anxiety, cancer, and wound healing with no or less side effects. Further, they are contributing a maximum role in cosmetics and perfume industries. However, the process of extraction through organic solvents might damage some important functional groups that are essential for healthcare benefits. To avoid this, most of the oil processing or pharmaceutical or cosmetic industry uses pectinase enzymes during the extraction process to destroy the emulsifying properties of pectin and promote the liquefaction of cell wall components, ultimately yielding a better volume of products. Moreover, the oils extracted through the enzymatic processes are enabled to retain the elevated concentration of phytocompounds like polyphenols, essential proteins, antioxidants, lipophilic bioactive compounds, and vitamin $\mathrm{E}$ with improving storage stability (157-160).

\section{Tablet Formulation}

In tablet formulations, currently, pectin hydrogels are widely used as binding agents that act as a controlled releasing agent, which are mostly used in colon cancer treatments. Hydrolyzed pectin beads are formulated by adopting the ionotropic gelation method and are used as a sustained-release drug delivery system. The modulation of low-methoxy pectin by esterification or implementation of calcium pectinate gel beads in formulations also supports the administration of the drug. Basically, calcium pectinate is used because of the development of insoluble hydrophilic coatings which further interact with each other in the host cell and helps in the smooth release of targeted medicine $(161,162)$. Furthermore, a report also suggested the effectiveness and controlled release of oral formulations with compacting the pectic substances which were derived from orange and mango peels. These are having an excellent impact with functional polymers and have outstanding binding properties during the formulation of various tablets $(163,164)$.

\section{Formulation for Lowering Blood Glucose and Cholesterol}

Direct pectin and/or pectic substances as obtained from pectinase treatment through the fermented process from the peels of various fruits and vegetables are being considered as a fruitful composition in pharma-based products due to their high fiber content. Scientists have reported and claimed that pectin is partially helping to prevent and treat severe diseases like diabetes and obesity, but it totally depends on the nature of viscosity, molecular weight, and degree of esterification. It is predicted that the more soluble fibers help to enhance gut viscosity, thus minimizing the re-absorption of bile acids. As a result, there is an increment of the synthesis of bile acids from cholesterol that helps the poor circulation of blood cholesterol. Herbal formulations related to this were tried in both in vitro and in vivo models by taking the digested pectins from the peels of apple, citrus, soybean etc. $(132,165,166)$.

\section{Cosmetic Formulation}

Currently, the pharmaceutical industry emphasizes on different cosmetic-related beauty products due to the most emerging demand by youths. The increasing environmental pollutants and unhealthy living practices have raised serious health impacts, including a detrimental impact on skin health. The pectic products are efficiently mixed with other chemicals for cosmetics as well as other personal care products which are found to be effective against various skin ailments. It is known not only for being a good emulsifier for thickening and gelling the face cream but also for its complex nature of polysaccharides that contain certain anti-oxidative and anti-aging properties that are able to prevent skin damage. However, the rate of efficacy may vary as per the sources from where it is extracted or fermented by respective pectinase enzymes (167-169).

\section{CONCLUSION}

The microbial research has created an irreversible renaissance in the present era of innovations and cutting-edge research for finding the novel utility of microorganisms and their products, which is a sheer reality. It is concluded that the role of pectinases and/or pectins is found to be curiously recognizable in various industrial processes, with promising results. From the extensive research, it is clear that pectinolytic enzymes become the key imperative to innovate strategies for the significant development or improvement of enzymes relevant to industrial products. However, it is one of the key critical factors to ensure the cost viability for the production of these enzymes from selective microorganisms and implemented environmental conditions. As evidenced, the application of pectinase and derived pectic substances are least explored with respect to their application in pharmaceutical products. Therefore, it is urgently needed to strengthen and expand the usage of such valuable enzymes in the pharmaceutical industry. Further, the intervention of biotechnological aspects is critically needed for the development of a broadspectrum pectinase with high catalytic affinities. Therefore, in-depth insights into a deeper understanding of the expression mechanism at the biochemical and molecular levels are essential.

\section{AUTHOR CONTRIBUTIONS}

SS and JR composed the first draft of the manuscript, whereas RK, HT, and SLS comprehensively edited the manuscript, which was then reviewed and edited by all authors.

\section{ACKNOWLEDGMENTS}

One of us (JR) is thankful to the authority of AIPH University for providing the platform to write this article. 


\section{REFERENCES}

1. Singh R, Kumar M, Mittal A, Kumar P. Microbial enzymes: industrial progress in 21st century. 3 Biotech. (2016) 6:174. doi: 10.1007/s13205-016-0485-8

2. Chapman J, Ismail A, Dinu C. Industrial applications of enzymes: recent advances, techniques, and outlooks. Catalysts. (2018) 8:238. doi: $10.3390 /$ catal 8060238

3. Gurung N, Ray S, Bose S, Rai V. A broader view: microbial enzymes and their relevance in industries, medicine, and beyond. Biomed Res Int. (2013) 2013:329121. doi: 10.1155/2013/329121

4. Nigam PS. Microbial enzymes with special characteristics for biotechnological applications. Biomolecules. (2013) 3:597611. doi: 10.3390/biom3030597

5. Kashyap DR, Vohra PK, Chopra S, Tewari R. Applications of pectinases in the commercial sector: a review. Bioresour Technol. (2001) 77:21527. doi: 10.1016/S0960-8524(00)00118-8

6. Chen J, Liu W, Liu C, Li T, Liang R, Luo S. Pectin modifications: a review. Crit Rev Food Sci Nutr. (2015) 55:1684-98. doi: 10.1080/10408398.2012.718722

7. Kittur FS, Kumar ABV, Gowda LR, Tharanathan RN. Chitosanolysis by a pectinase isozyme of Aspergillus niger-a non-specific activity. Carbohydr Polym. (2003) 53:191-6. doi: 10.1016/S0144-8617(03)00042-0

8. Verma H, Narnoliya LK, Jadaun JS. Pectinase: a useful tool in fruit processing industries. Nutr Food Sci Int J. (2018) 5:555673. doi: 10.19080/NFSIJ.2018.05.555673

9. Raju EVN, Divakar G. Production of pectinase by using Bacillus circulans isolated from dump yards of vegetable wastes. Int J Pharm Sci Res. (2013) 4:2615-2622. doi: 10.13040/IJPSR.0975-8232.4(7).2615-22

10. Garg G, Singh A, Kaur A, Singh R, Kaur J, Mahajan R. Microbial pectinases: an ecofriendly tool of nature for industries. 3 Biotech. (2016) 6:47-59. doi: 10.1007/s13205-016-0371-4

11. Minten IJ, Abello N, Schooneveld-Bergmans MEF, van den Berg MA. Postproduction modification of industrial enzymes. Appl Microbiol Biotechnol. (2014) 98:6215-31. doi: 10.1007/s00253-014-5799-Z

12. Xu Z, Cen Y, Zou S, Xue Y, Zheng Y. Recent advances in the improvement of enzyme thermostability by structure modification. Crit Rev Biotechnol. (2020) 40:83-98. doi: 10.1080/07388551.2019.1682963

13. Jayani RS, Saxena S, Gupta R. Microbial pectinolytic enzymes: a review. Process Biochem. (2005) 40:2931-44. doi: 10.1016/j.procbio.2005.03.026

14. Bhardwaj V, Degrassi G, Bhardwaj RK. Microbial pectinases and their applications in industries: a review. Int Res J Eng Technol. (2017) 4:829-36. doi: 10.1007/s00253-002-1061-1

15. Wilkowska A, Nowak A, Antczak-Chrobot A, Motyl I, Czyzowska A, Paliwoda A. Structurally different pectic oligosaccharides produced from apple pomace and their biological activity in vitro. Foods. (2019) 8:365. doi: 10.3390/foods8090365

16. Wu C, Pan LL, Niu W, Fang X, Liang W, Li J, et al. Modulation of gut microbiota by low methoxyl pectin attenuates type 1 diabetes in non-obese diabetic mice. Front Immunol. (2019) 10:1733. doi: 10.3389/fimmu.2019.01733

17. Chamani E, Tahami SK, Zare N, Asghari-Zakaria R, Mohebodini M, Joyce D. Effect of different cellulase and pectinase enzyme treatments on protoplast isolation and viability in Lilium ledebeourii Bioss. Not Bot Horti Agrobot. (2012) 40:123-8. doi: 10.15835/nbha4028055

18. Oumer OJ, Abate D. Screening and molecular identification of pectinase producing microbes from coffee pulp. Biomed Res Int. (2018) 2018:2961767. doi: 10.1155/2018/2961767

19. Bharadwaj PS, Udupa PM. Isolation, purification and characterization of pectinase enzyme from Streptomyces thermocarboxydus. J Clin Microbiol Biochem Technol. (2019) 5:31. doi: 10.17352/jcmbt.000031

20. Sandri IG, Silveira MM. Production and application of pectinases from Aspergillus niger obtained in solid state cultivation. Beverages. (2018) 4:48. doi: 10.3390/beverages 4030048

21. Guan Y, Wang D, Lv C, Zhang Y, Gelvic I, Ye X. Archives of microbiology: screening of pectinase-producing bacteria from citrus peel and characterization of a recombinant pectate lyase with applied potential. Arch Microbiol. (2020) 202:1005-13. doi: 10.1007/s00203-020-0 1893-0
22. Hasan R, Aktar N, Kabir SMT, Honi U, Halim A, Islam R, et al. Pectinolytic bacterial consortia reduce jute retting period and improve fibre quality. Sci Rep. (2020) 10:5174. doi: 10.1038/s41598-020-61898-z

23. Subramaniyam R, Vimala R. Solid state and submerged fermentation for the production of bioactive substances: a comparative study. Int J Sci Nat. (2012) 3:480-6.

24. Doriya K, Jose N, Gowda M, Kumar DS. Solid-state fermentation vs submerged fermentation for the production of L-asparaginase. Adv Food Nutr Res. (2016) 78:115-35. doi: 10.1016/bs.afnr.2016.05.003

25. Ravindran R, Jaiswal AK. Microbial enzyme production using lignocellulosic food industry wastes as feedstock: a review. Bioengineering. (2016) 3:30. doi: 10.3390/bioengineering 3040030

26. Lizardi-Jimenez MA, Hernandez-Martinez R. Solid state fermentation (SSF): diversity of applications to valorize waste and biomass. 3 Biotech. (2017) 7:44. doi: 10.1007/s13205-017-0692-y

27. Hours RA, Sakai T. Protopectinase production in solid state culture of Aspergillus awamori. Biotechnol Lett. (1994) 16:7216. doi: 10.1007/BF00136478

28. Cavalitto, SF, Hours RA, Mignone CF. Growth and protopectinase production of Geotrichum klebahnii in batch and continuous cultures with synthetic media. J Ind Microbiol Biotechnol. (2000) 25:260-5. doi: 10.1038/sj.jim.7000072

29. Fan C, Liu Z, Yao L. Medium optimization for protopectinase production by batch culture of Aspergillus terreus. Afr J Biotechnol. (2011) 10:1757178. doi: 10.5897/AJB11.2617

30. Zhang J, Zhao L, Gao B, Wei W, Wang H, Xie J. Protopectinase production by Paenibacillus polymyxa Z6 and its application in pectin extraction from apple pomace. J Food Process Preserv. (2017) 2017:e13367. doi: 10.1111/jfpp.13367

31. Joshi VK, Parmar M, Rana NZ. Pectin esterase production from apple pomace in solid-State and SmFs. Food Technol Biotechnol. (2006) 44:253-6. Available online at: https://www.ftb.com.hr/images/pdfarticles/2006/AprilJune/44-253.pdf

32. Mandhania S, Jain V, Malhotra SP. Culture optimization for enhanced production of microbial pectin methylesterase under submerged conditions. Asian J Biochem. (2010) 5:12-22. doi: 10.3923/ajb.2010.12.22

33. Gayen S, Ghosh U. Pectinmethylesterase production from mixed agrowastes by Penicillium notatum NCIM. 923 in solid-state fermentation. J Bioremed Biodegrad. (2011) 2:119. doi: 10.4172/2155-6199.1000119

34. Glinka EM, Liao YC. Purification and partial characterisation of pectin methylesterase produced by Fusarium asiaticum. Fungal Biol. (2011) 115:1112-21. doi: 10.1016/j.funbio.2011.07.005

35. Bastos SC, Pimenta CJ, Dias DR, Chalfoun SM, Angelico CL, Tavares LS. Pectinases from a new strain of Cladosporium cladosporioides (Fres.) De Vries isolated from coffee bean. World J Agric Sci. (2013) 9:167-72. Available online at: http://repositorio.ufla.br/jspui/handle/1/4487

36. Patidar MK, Nighojkar A, Nighojkar S, Kumar A. Purification and characterization of pectin methylesterase produced in SSF by Aspergillus tubingensis. Br Biotechnol J. (2016) 12:1-10. doi: 10.9734/BBJ/2016/23632

37. Salehghamari E, Nasrollahzadeh Z, Tahmaseb M, Amoozegar MA. Pectinase enzyme from Streptomyces coelicoflavus GIAL86 isolated from Meyghan Salt Lake, Arak, Iran. Int J Aquat Biol. (2019) 7:106-11. doi: 10.22034/ijab.v7i2.481

38. Shevchik VE, Hugouvieux-Cotte-Pattat N. PaeX, a second pectin acetylesterase of Erwinia chrysanthemi 3937. J Bacteriol. (2003) 185:3091-100. doi: 10.1128/JB.185.10.3091-3100.2003

39. Polizeli MDLTM, Jorge JA, Terenzi HF. Pectinase production by Neurospora crassa: purification and biochemical characterization of extracellular polygalacturonase activity. J Gen Microbiol. (1991) 137:1815-23. doi: 10.1099/00221287-137-8-1815

40. Teixeira MFS, Filho JLL, Duran N. Carbon sources effect on pectinase production from Aspergillus japonicus 586. Braz J Microbiol. (2000) 31:28690. doi: 10.1590/S1517-83822000000400009

41. Soares MMCN, Da Silva R, Carmona EC, Gomes E. Pectinolytic enzyme production by Bacillus species and their potential application on juice extraction. World J Microbiol Biotechnol. (2001) 17:79-82. doi: 10.1023/A:1016667930174

42. Almeida C, Branyik T, Moradas-Ferreira P, Teixeira J. Continuous production of pectinase by immobilized yeast cells on spent grains. 
$J \quad$ Biosci Bioeng. (2003) 96:513-8. doi: 10.1016/S1389-1723(04) 70142-5

43. Botella C, de Orya I, Webbb C, Canteroa D, Blandino A. Hydrolytic enzyme production by Aspergillus awamori on grape pomace. Biochem Eng J. (2005) 26:100-6. doi: 10.1016/j.bej.2005.04.020

44. Phutela U, Dhuna V, Sandhu S, Chadha BS. Pectinase and polygalacturonase production by a thermophilic Aspergillus fumigatus isolated from decomposting orange peels. Braz. J. Microbiol. (2005) 36:63-9. doi: 10.1590/S1517-83822005000100013

45. Radoi F, Kishida M, Kawasaki H. Endo-polygalacturonase in Saccharomyces wine yeasts: effect of carbon source on enzyme production. FEMS Yeast Res. (2005) 5:663-8. doi: 10.1016/j.femsyr.2004.09.006

46. Bayoumi RA, Yassin HM, Swelim MA, Abdel-All EZ. Production of bacterial pectinase(s) from agro-industrial wastes under SSF conditions. J Appl Sci Res. (2008) 4:1708-21. Available online at: http://www.aensiweb.com/old/ jasr/jasr/2008/1708-1721.pdf

47. Pedrolli DB, Gomes E, Monti R, Carmona EC. Studies on productivity and characterization of polygalacturonase from Aspergillus giganteus submerged culture using citrus pectin and orange waste. Appl Biochem Biotechnol. (2008) 144:191-200. doi: 10.1007/s12010-007-8059-1

48. Rashmi R, Siddalingamurthy KR, Sneha G, Shabana S, Syama A, Radhika VS. Partial purification and biochemical characterization of extracellular pectinase from Aspergillus niger isolated from groundnut seeds. J Appl Biosci. (2008) 9:378-84.

49. Taskin W, Eltem R, da Silva ES, de Souza JVB. Screening of Aspergillus strains isolated from vineyards for pectinase production. J Food Agric Environ. (2008) 6:412-4. doi: 10.1234/4.2008.1364

50. Banu AR, Devi MK, Gnanaprabhal GR, Pradeep BV, Palaniswamy M. Production and characterization of pectinase enzyme from Penicillium chrysogenum. Ind J Sci Technol. (2010) 3:37781. doi: $10.17485 / \mathrm{ijst} / 2010 / \mathrm{v} 3 \mathrm{i} 4.10$

51. Patil NP, Chaudhari BL. Production and purification of pectinase by soil isolate Penicillium sp and search for better agro-residue for its SSF. Recent Res Sci Technol. (2010) 2:36-42. Available online at: https://pdfs.semanticscholar. org/a640/845c165ae2090b36972eb7c3cbb506669724.pdf

52. Thakur A, Pahwa R, Singh S, Gupta R. Production, purification and characterization of polygalacturonase from Mucor circinelloides ITCC6025. Enz Res. (2010) 2010:170549. doi: 10.4061/2010/170549

53. Janani L, Karthik GK, Rao KVB. Screening of pectinase producing microorganisms from agricultural waste dump. Asian J Biochem Pharm Res. (2011) 1:329-37.

54. Namasivayam E, Ravindar JD, Mariappan K, Jiji A, Kumar M, Jayaraj RL. Production of extracellular pectinase by Bacillus cereus isolated from market solid waste. J Bioanal Biomed. (2011) 3:070-5. doi: 10.4172/1948-593X.1000046

55. Banakar SP, Thippeswamy B. Isolation, production and partial purification of fungal extracellular pectinolytic enzymes from the forest soils of bhadra wildlife sanctuary, Western Ghats of Southern India. J Biochem Tech. (2012) 3:S138-43. Available online at: https://shodhganga.inflibnet.ac.in/ bitstream/10603/81732/17/18_appendices.pdf

56. Chiliveri SR, Panda SH, Rao LV. Isolation and screening of polygalacturonase-producing Bacillus sp. Dyn Biochem Process Biotechnol Mol Biol. (2012) 6:123-6. Availbale online at: http://www. globalsciencebooks.info/Online/GSBOnline/images/2012/DBPBMB_6(SI1)/ DBPBMB_6(SI1)123-126o.pdf

57. Ezugwu AL, Eze SOO, Chilaka FC, Anyanwu CU. Production and characterization of pectinases obtained from Aspergillus fumigatus in submerged fermentation system using pectin extracted from mango peels as carbon source. Plant Prod Res J. (2012) 16:30-6. Available online at: https:// www.ajol.info/index.php/pprj/article/view/97922

58. Kumar YS, Kumar PV, Reddy OVS. Pectinase production from mango peel using Aspergillus foetidus and its application in processing of mango juice. Food Biotechnol. (2012) 26:107-23. doi: 10.1080/08905436.2012.6 70830

59. Oyeleke SB, Oyewole OA, Egwim EC, Dauda BEN, Ibeh EN. Cellulase and pectinase production potentials of Aspergillus niger isolated from corn cob. Bayero J Pure Appl Sci. (2012) 5:78-83. doi: 10.4314/bajopas.v5i1.15
60. Siddiqui MA, Pande V, Arif M. Production, purification and characterization of polygalacturonase from Rhizomucor pusillus isolated from decomposting orange peels. Enzyme Res. (2012) 2012:138634. doi: 10.1155/2012/138634

61. Anisa SK, Ashwini S, Girish K. Isolation and screening of Aspergillus spp for pectinolytic activity. Elect J Biol. (2013) 9:37-41. Available online at: https://ejbio.imedpub.com/isolation-and-screening-of-aspergillussppforpectinolytic-activity.php?aid $=5973$

62. Darah I, Haritharan W, Lim SH. Involvement of physicochemical parameters on pectinase production by Aspergillus niger HFD5A-1. J Pure Appl Microbiol. (2013) 7:2541-49. Available online at: https:// microbiologyjournal.org/archive_mg/jmabsread.php?snoid=1534\& month $=$ \&year

63. Maciel M, Ottoni C, Santos C, Lima N, Moreira K, SouzaMotta C. Production of polygalacturonases by Aspergillus section Nigri strains in a fixed bed reactor. Molecules. (2013) 18:1660-71. doi: 10.3390/molecules 18021660

64. Martos MA, Zubreski ER, Combina M, Garro OA, Hours RA. Isolation of a yeast strain able to produce a polygalacturonase with maceration activity of cassava roots. Food Sci Technol. (2013) 33:332-8. doi: 10.1590/S0101-20612013005000047

65. Mehta SA, Rana M, Shaikh N, Patel N. Optimization of physiological parameters for pectinase production from soil isolates and its applications in fruit juice clarification. J Environ Res Dev. (2013) 7:1539-46. doi: 10.21275/ART20179549

66. Varghese LK, Rizvi AF, Gupta AK. Isolation, screening and biochemical characterization of pectinolytic microorganism from soil sample of Raipur city. J Biol Chem Res. (2013) 30:636-43. Available online at: http:// www.jbcr.co.in/Current_Issue/Volume\%2030\%20\%282\%29\%20July\%20to \%20December\%202013\%20B/Isolation-Screening-and-Biochemical.pdf

67. Gogus N, Hakguder Taze B, Demir H, Tari C, Unluturk S, Lahore MF. Evaluation of orange peel, an industrial waste, for the production of Aspergillus sojae polygalacturonase considering both morphology and rheology effects. Turk J Biol. (2014) 38:537-48. doi: 10.3906/biy-1308-47

68. Naveenkumar KJ, Thippeswamy B, Krishnappa M. Production and partial purification of fungal pectinases from Areca nut (Areca catechu L.) husk waste under SmF. Int J Adv Biotechnol Res. (2014) 5:188-201. Available online at: http://bipublication.com/files/IJABR-V5I2-2014-17.pdf

69. Osuigwe MJ, Nkem T, Emuebie OR, Isreal J, Kayode AF. Physicochemical factors influencing pectinolytic enzyme produced by Bacillus licheniformis under SmF. Nat. Sci. (2014) 12:110-6. Available online at: http://www. sciencepub.net/nature/ns1208/015_26385ns120814_110_116.pdf

70. Priya V, Sashi V. Pectinase enzyme production by using agrowastes. Int J Eng Sci Res Technol. (2014) 3:8041-6. Available online at: http://citeseerx.ist.psu. edu/viewdoc/summary?doi=10.1.1.683.7206

71. Thangaratham T, Manimegalai G. Optimization and production of pectinase using agro waste by solid state and SmF. Int J Curr Microbiol Appl Sci. (2014) 3:357-65. Available online at: https://www.ijcmas.com/vol-3-9/T. Thangaratham\%20and\%20G.Manimegalai.pdf

72. Udenwobele DI, Nsude CA, Ezugwu AL, Eze SOO, Anyawu C, Uzoegwu $\mathrm{PN}$, et al. Extraction, partial purification and characterization of pectinases isolated from Aspergillus species cultured on mango (Mangifera indica) peels. Afr J Biotechnol. (2014) 13:2445-54. doi: 10.5897/AJB2014.13771

73. Barman S, Sit N, Badwaik LS, Deka SC. Pectinase production by Aspergillus niger using banana (Musa balbisiana) peel as substrate and its effect on clarification of banana juice. J Food Sci Technol. (2015) 52:357989. doi: 10.1007/s13197-014-1413-8

74. Jabeen A, Hanif QA, Hussain M, Munawar A, Farooq N, Bano S. Screening, isolation and identification of pectinase producing bacterial strains from rotting fruits and determination of their pectinolytic activity. Sci Lett. (2015) 3:42-5. Available online at: https://pdfs.semanticscholar.org/2958/ 941a1f96df9b6d3b1f205d10380e6a6571f1.pdf

75. Khatri BP, Bhattarai T, Shrestha S, Maharjan J. Alkaline thermostable pectinase enzyme from Aspergillus niger strain MCAS2 isolated from Manaslu conservation area, Gorkha, Nepal. SpringerPlus. (2015) 4:488. doi: 10.1186/s40064-015-1286-y

76. Ahmed I, Zia MA, Hussain MA, Akram Z, Naveed MT, Nowrouzi A. Bioprocessing of citrus waste peel for induced pectinase production by 
Aspergillus niger; its purification and characterization. J Rad Res Appl Sci. (2016) 9:148-154. doi: 10.1016/j.jrras.2015.11.003

77. Jaramillo PMD, Andreaus J, Neto GPDS, Castro CFDS, Filho EXF. The characterization of a pectin-degrading enzyme from Aspergillus oryzae grown on passion fruit peel as the carbon source and the evaluation of its potential for industrial applications. Biocatal Biotransform. (2016) 33:31022. doi: 10.3109/10242422.2016.1168817

78. Takei HAM, Turkmen FU. Extracellular pectinase production and purification from a newly isolated Bacillus subtilis strain. Int J Food Prop. (2016) 19:2443-50. doi: 10.1080/10942912.2015.11 23270

79. Anand G, Yadav S, Yadav D. Production, purification and biochemical characterization of an exo-polygalacturonase from Aspergillus niger MTCC 478 suitable for clarification of orange juice. 3 Biotech. (2017) 7:122. doi: 10.1007/s13205-017-0760-3

80. Jahan N, Shahid F, Aman A, Mujahid TL, Ul Qader SA. Utilization of agro waste pectin for the production of industrially important polygalacturonase. Heliyon. (2017) 3:e00330. doi: 10.1016/j.heliyon.2017.e 00330

81. Abdullah R, Farooq I, Kaleem A, Iqtedar M, Iftikhar T. Pectinase production from Aspergillus niger IBT-7 using SSF. Bangladesh J Bot. (2018) 47:4738. doi: 10.3329/bjb.v47i3.38714

82. Abdullah R, Jafer A, Nisar K, Kaleem A, Iqtedar M, Iftikhar T, et al. Process optimization for pectinase production by locally isolated fungal strain using SmF. Biosci J. (2018) 34:1025-32. doi: 10.14393/BJ-v34n1a2018-39947

83. Dange VU, Harke S. Production and purification of pectinase by fungal strain in solid-state fermentation using agro-industrial bioproduct. Int J Life Sci Res. (2018) 6:85-93. Available online at: https://researchpublish.com/issue/ IJLSR/Issue-4-October-2018-December-2018/3

84. Ketipally R, Ram MR. Optimization of pectinase production by Aspergillus oryzae RR 103. Curr Agric Res. (2018) 6:37-44. doi: 10.12944/CARJ.6.1.05

85. Roy K, Dey S, Uddin MK, Barua R, Hossain MT. Extracellular pectinase from a novel bacterium Chryseobacterium indologenes strain SD and its application in fruit juice clarification. Enzyme Res. (2018) 2018:3859752. doi: 10.1155/2018/3859752

86. Carrasco M, Rozas JM, Alcaino J, Cifuentes V, Baeza M. Pectinase secreted by psychrotolerant fungi: identification, molecular characterization and heterologous expression of a cold-active polygalacturonase from Tetracladium sp. Microb Cell Fact. (2019) 18:45. doi: 10.1186/s12934-019-1092-2

87. Guo F, Li X, Zhao J, Li G, Gao P, Han X. Optimizing culture conditions by statistical approach to enhance production of pectinase from Bacillus sp. Y1. BioMed Res Int. (2019) 2019:1-10. doi: 10.1155/2019/8146948

88. Jadhav SR, Pathak AP. Production and characterization of a thermo-pH stable pectinase from Bacillus licheniformis UNP-1: a novel strain isolated from Unapdev hot spring. Ind J Geo Marine Sci. (2019) 48:670-7. Available online at: http://nopr.niscair.res.in/handle/123456789/47423

89. Koshy M, De S. Effect of Bacillus tequilensis SALBT crude extract with pectinase activity on demucilation of coffee beans and juice clarification. $J$ Basic Microbiol. (2019) 59:1185-94. doi: 10.1002/jobm.201900321

90. Okonji RE, Itakorode BO, Ovumedia JO, Adedeji OA. Purification and biochemical characterization of pectinase produced by Aspergillus fumigatus isolated from soil of decomposing plant materials. J Appl Biol Biotechnol. (2019) 7:1-8. doi: 10.7324/JABB.2019.70301

91. Pagarraa H, Rahman RA, Rachmawaty Manas NHA. Screening of factors influencing exopolygalacturonase production by Aspergillus niger ATCC 120120 using two-level fractional factorial design. J Teknol. (2019) 81:7380. doi: $10.11113 /$ jt.v81.13638

92. Prasad B, Goyal S. Effects of carbon and process parameters on the production of pectinase by Aspergillus spp. isolated from rotten citrus fruits. Int J Innovat Biol Chem Sci. (2019) 12:1-10. Available online at: https://www. whitesscience.com/wp-content/uploads/woocommerce_uploads/2019/10/ IJIBCS_12_1-10-1.pdf?

93. Zhang G, Li S, Xu Y, Wang J, Wang F, Xin Y, et al. Production of alkaline pectinase: a case study investigating the use of tobacco stalk with the newly isolated strain Bacillus tequilensis CAS-MEI-2-33. BMC Biotechnol. (2019) 19:45. doi: 10.1186/s12896-019-0526-6
94. Ahmed A, Ejaz U, Sohail M. Pectinase production from immobilized and free cells of Geotrichum candidum AA15 in galacturonic acid and sugars containing medium. J King Saud Univ Sci. (2020) 32:9524. doi: 10.1016/j.jksus.2019.07.003

95. Amin F, Mohsin A, Bhatti HN, Bilal M. Production, thermodynamic characterization and fruit juice quality improvement characteristics of an exo-polygalacturonase from Penicillium janczewskii. Biochim Biophys Acta Proteins Proteom. (2020) 1868:140379. doi: 10.1016/j.bbapap.2020.140379

96. Arekemase MO, Omotosho IO, Agbabiaka TO, Ajide-Bamigboye NT, Lawal AK, Ahmed T, et al. Optimization of bacteria pectinolytic enzyme production using banana peel as substrate under SmF. Sci World J. (2020) 15:56-63. Available online at: https://www.scienceworldjournal.org/article/view/20220

97. El Garhy GM, Azzaz HH, Abd El Mola AM, Mousa GA. Fungal pectinase production optimization and its application in buffaloe's diets degradation. Int J Zool Anim. Biol. (2020) 3:000199. doi: 10.23880/izab-16000199

98. Khalil M, Khattak S, Ali Q, Qureshi JA, Malik A. Isolation and characterization of pectinase producing Aspergillus niger from orange. Int J Bot Stud. (2020) 5:45-8. Available online at: http://www.botanyjournals. com/archives/2020/vol5/issue2/5-1-55

99. Swami CS. Effect of supplementation of amino acids on pectinase production in tomato fungi. Int J Sci. Res. (2020) 9:37-8. doi: 10.36106/ijsr

100. Swami CS. Studies on pectinase production in tomato fungi on different culture media. Indian J Appl Res. (2020) 10:50-1. doi: 10.36106/ijar/9613775

101. Zehra M, Syed MN, Sohail M. Banana peels: a promising substrate for the coproduction of pectinase and xylanase from Aspergillus fumigatus MS16. Pol J Microbiol. (2020) 69:19-26. doi: 10.33073/pjm-2020-002

102. Molina SMG, Pelissari FA, Vitorello CBM. Screening and genetic improvement of pectinolytic fungi for degumming of textile fibers. Braz J Microbiol. (2001) 32:320-6. doi: 10.1590/S1517-83822001000400013

103. Piccoli-Valle RH, Passos FML, Passos FJV, Silva DO. Production of pectin lyase by Penicillium griseoroseum in bioreactors in the absence of inducer. Braz J Microbiol. (2001) 32:135-40. doi: 10.1590/S1517-83822001000200013

104. Mehmood T, Saman T, Irfan M, Anwar F, Ikram MS, Tabassam Q. Pectinase production from Schizophyllum commune through central composite design using citrus waste and its immobilization for industrial exploitation. Waste Biomass Valor. (2019) 10:2527-36. doi: 10.1007/s12649-018-0279-9

105. Zhen J, Tan M, Fu X, Shu W, Zhao X, Yang S, et al. High-level extracellular production of an alkaline pectate lyase in E. coli BL21 (DE3) and its application in bioscouring of cotton fabric. 3 Biotech. (2020) 10:49. doi: 10.1007/s13205-019-2022-z

106. Sakai T. Degradation of pectins. In: Winkelmann G, editor. Microbial Degradation of Natural Products. Michigan: Wiley Publishers (1992). p. 57-81.

107. Garg N, Singh VK. Carbohydrate metabolism during fruit spoilage. In Peter $\mathrm{KV}$, editor. Biotechnology in horticulture: Methods and Applications. New Delhi: NIPA (2013). p. 179-97.

108. Brinton CS, Dore WH, Wichmann HJ, Willaman JJ, Wilson CP. Definitions written by the committee on nomenclature of pectin of the agriculture-food division. J Am Chem Soc. (1927) 49:38-40.

109. Sakai T, Sakamoto T, Hallaert J, Vandamme EJ. Pectin, pectinase, and protopectinase: production, properties, and applications. Adv Appl Microbiol. (1993) 39:213-94. doi: 10.1016/S0065-2164(08)70597-5

110. Pedrolli AC, Gomes E, Carmona EC. Pectin and pectinases: production, characterization and industrial application of microbial pectinolytic enzymes. Open Biotechnol J. (2009) 3:9-18. doi: 10.2174/1874070700903010009

111. Sakai T. Protopectinase from yeasts and a yeastlike fungus. Methods Enzymol. (1988) 161:335-50. doi: 10.1016/0076-6879(88)61038-X

112. Whitaker JR. Microbial pectinolytic enzymes. In: Fogarty WM, Kelly CT, editors. Microbial Enzymes and Biotechnology. 2nd ed. London: Elsevier Science Ltd (1990). p. 133-76. doi: 10.1007/978-94-009-0765-2_4

113. Sakai T, Takao M, Nagai $M$. Research on protopectinase: a new aspect of research on pectolytic enzymes. Mem Fac Agric Kinki Univ. (1999) 32:1-19.

114. Voragen AGJ, Coenen GJ, Verhoef RP, Schols HA. Pectin, a versatile polysaccharide present in plant cell walls. Struc Chem. (2009) 20:263. doi: 10.1007/s11224-009-9442-z 
115. Patidar MK, Nighojkar S, Kumar A, Nighojkar A. Pectinolytic enzymes-solid state fermentation, assay methods and applications in fruit juice industries: a review. 3 Biotech. (2018) 8:199. doi: 10.1007/s13205-018-1220-4

116. Micheli F. Pectin methylesterases: cell wall enzymes with important roles in plant physiology. Trends Plant Sci. (2001) 6:414-9. doi: 10.1016/S1360-1385(01)02045-3

117. Vicente CSL, Nemchinov LG, Mota M, Eisenback JD, Kamo K, Vieira P. Identification and characterization of the first pectin methylesterase gene discovered in the root lesion nematode Pratylenchus penetrans. PLoS ONE. (2019) 14:e0212540. doi: 10.1371/journal.pone.0212540

118. Sumner JB, Frederick G. Chemistry and Methods of Enzymes. New York, NY: Academic Press Inc. (1953). p. 68-105. doi: 10.1016/B978-1-4832-3150-1.50009-3

119. Gummadi SN, Manoj N, Kumar DS. Structural and biochemical properties of pectinases. In: Polaina J, MacCabe AP, editors. Industrial Enzymes. Dordrecht: Springer (2007). p. 99-115. doi: 10.1007/1-4020-5377-0_7

120. Jenkins J, Mayans O, Smith D, Worboys K, Pickersgill RW. Threedimensional structure of Erwinia chrysanthemi pectin methylesterase reveals a novel esterase active site. J Mol Biol. (2001) 305:95160. doi: 10.1006/jmbi.2000.4324

121. Shevchik VE, Condemine G, Hugouvieux-Cotte-Pattat N, Robert-Baudouy J. Characterization of pectin methylesterase B, an outer membrane lipoprotein of Erwinia chrysanthemi 3937. Mol Microbiol. (1996) 19:45566. doi: 10.1046/j.1365-2958.1996.389922.x

122. Kwon SJ, Son JH, Park KC, Oh HY, Kim PH, Byeon WH, et al. Structural dynamics and divergence of the polygalacturonase gene family in land plants. Nat Prec. (2008) 49:1-34. doi: 10.1038/npre.2008.1608.1

123. Yang Y, Yu Y, Liang Y, Anderson CT, Cao J. A profusion of molecular scissors for pectins: classification, expression, and functions of plant polygalacturonases. Front Plant Sci. (2018) 9:1208. doi: 10.3389/fpls.2018.01208

124. Mutter M, Beldman G, Pitson SM, Schols HA, Voragen AGJ. Rhamnogalacturonan $\alpha-\mathrm{D}$-galactopyranosyluronohydrolase. Plant Physiol. (1998) 117:153-63. doi: 10.1104/pp.117.1.153

125. Barnby FM, Morpeth FF, Pyle DL. Endopolygalacturonase production from Kluyveromyces marxianus. I. Resolution, purification and partial characterization of the enzyme. Enzyme Microb. Technol. (1990) 12:8917. doi: 10.1016/0141-0229(90)90028-O

126. Shevchik VE, Condemine G, Robert-Baudouy J, Hugouvieux-Cotte-Pattat N. The exopolygalacturonate lyase PelW and the oligogalacturonate lyase Ogl, two cytoplasmic enzymes of pectin catabolism in Erwinia chrysanthemi 3937. J Bacteriol. (1999) 181:3912-9. doi: 10.1128/JB.181.13.3912-3919.1999

127. Yadav SK, Yadav PK, Yadav D, Yadav KDS. Pectin lyase: a review. Process Biochem. (2009) 44:1-10. doi: 10.1016/j.procbio.2008.09.012

128. Weber J, Olsen O, Wegener C, von Wettstein D. Digalacturonates from pectin degradation induce tissue responses against potato soft rot. Physiol Mol Plant Pathol. (1996) 48:389-401. doi: 10.1006/pmpp.1996.0031

129. Couri S, Terzi SC, Ribeiro BD, da Costa ACA, Farinas CS. Methods of determination of pectinase activity. In: Vermelho AB, Couri S, editors. Methods to Determine Enzymatic Activity. Sharjah: Bentham Science Publishers (2013). p. 3-26.

130. Mayans O, Scott M, Connerton I, Gravesen T, Benen J, Visser J, et al. Two crystal structures of pectin lyase A from Aspergillus reveal a $\mathrm{pH}$ driven conformational change and striking divergence in the substratebinding clefts of pectin and pectate lyases. Structure. (1997) 5:67789. doi: 10.1016/S0969-2126(97)00222-0

131. Mohnen D. Pectin structure and biosynthesis. Curr Opin Plant Biol. (2008) 11:266-77. doi: 10.1016/j.pbi.2008.03.006

132. Lara-Espinoza C, Carvajal-Millán E, Balandrán-Quintana R, LópezFranco $Y$, Rascón-Chu A. Pectin and pectin-based composite materials: beyond food texture. Molecules. (2018) 23:942. doi: 10.3390/molecules23040942

133. Yapo BM, Lerouge P, Thibault JF, Ralet MC. Pectins from citrus peel cell walls contain homogalacturonans homogenous with respect to molar mass, rhamnogalacturonan I and rhamnogalacturonan II. Carbohydr Polym. (2007) 69:426-35. doi: 10.1016/j.carbpol.2006.12.024

134. Kang HJ, Jo C, Kwon JH, Son JH, An BJ, Byun MW. Antioxidant and cancer cell proliferation inhibition effect of citrus pectin oligosaccharide prepared by irradiation. J Med Food. (2006) 9:313-20. doi: 10.1089/jmf.2006.9.313
135. Olano-Martin E, Gibson GR, Rastall RA. Comparison of the in vitro bifidogenic properties of pectins and pectic-oligosaccharides. J Appl Microbiol. (2002) 93:505-11. doi: 10.1046/j.1365-2672.2002. 01719.x

136. Maxwell EG, Belshaw NJ, Waldron KW, Morris VJ. Pectin-an emerging new bioactive food polysaccharide. Trends Food Sci Technol. (2012) 24:6473. doi: 10.1016/j.tifs.2011.11.002

137. Xu Y, Dong Q, Qiu H, Ma CW, Ding K. A homogalacturonan from the radix of Platycodon grandiflorum and the anti-angiogenesis activity of poly/oligogalacturonic acids derived therefrom. Carbohydr Res. (2011) 346:19306. doi: 10.1016/j.carres.2011.05.011

138. Renard CMGC, Thibault JF. Degradation of pectins in alkaline conditions: kinetics of demethylation. Carbohydr Res. (1996) 286:139-50. doi: 10.1016/0008-6215(96)00056-0

139. Krall SM, McFeeters RF. Pectin hydrolysis: effect of temperature, degree of methylation, pH, and calcium on hydrolysis rates. J Agric Food Chem. (1998) 46:1311-5. doi: 10.1021/jf970473y

140. Benen JA, Visser J. Polygalacturonases. In: Whitaker J, Voragen A, Wong D, editors. Handbook of Food Enzymology. New York, NY: Marcel Gekker Inc. (2003). p. 857-66.

141. de Vries RP, Kester HC, Poulsen CH, Benen JA, Visser J. Synergy between enzymes from Aspergillus involved in the degradation of plant cell wall polysaccharides. Carbohydr Res. (2000) 327:401-10. doi: 10.1016/S0008-6215(00)00066-5

142. de Vries RP, Visser J. Aspergillus enzymes involved in degradation of plant cell wall polysaccharides. Microbiol Mol Biol Rev. (2001) 65:497522. doi: 10.1128/MMBR.65.4.497-522.2001

143. de Vries RP. Regulation of Aspergillus genes encoding plant cell wall polysaccharide-degrading enzymes; relevance for industrial production. Appl Microbiol Biotechnol. (2003) 61:10-20. doi: 10.1007/s00253-002-1171-9

144. Caffall KH, Mohnen D. The structure, function, and biosynthesis of plant cell wall pectic polysaccharides. Carbohydr Res. (2009) 344:1879900. doi: 10.1016/j.carres.2009.05.021

145. Daher FB, Braybrook SA. How to let go: pectin and plant cell adhesion. Front Plant Sci. (2015) 6:523. doi: 10.3389/fpls.2015.00523

146. Gawkowska D, Cybulska J, Zdunek A. Structure-related gelling of pectins and linking with other natural compounds: a review. Polymers. (2018) 10:762. doi: $10.3390 /$ polym 10070762

147. Kameshwar AKS, Qin W. Structural and functional properties of pectin and lignin-carbohydrate complexes de-esterases: a review. Bioresour Bioprocess. (2018) 5:43. doi: 10.1186/s40643-018-0230-8

148. Reddy L, Sreeramulu A. Isolation, identification and screening of pectinolytic fungi from different soil samples of Chittoor district. Int. J. Life Sci Biotechnol Pharm Res. (2012) 1:186-93. Available online at: http://www.ijlbpr.com/ index.php? $\mathrm{m}=$ content $\& \mathrm{c}=$ index $\& \mathrm{a}=$ show \& $\mathrm{catid}=116 \& \mathrm{~d}=400$

149. Venkatanagaraju E, Bharathi N, Sindhuja RH, Chowdhury RR, Sreelekha Y. Extraction and purification of pectin from agro-industrial wastes. In: Masuelli M, editor. Pectins-Extraction, Purification, Characterization and Applications. IntechOpen (2019). p. 1-15. doi: 10.5772/intechopen.85585

150. Sandarani MD. A review: different extraction techniques of pectin. $J$ Pharmacogn Nat Prod. (2017) 3:1-5. doi: 10.4172/2472-0992.1000143

151. Kute AB, Mohapatra D, Kotwaliwale N, Giri SK, Sawant BP. Characterization of pectin extracted from orange peel powder using microwave-assisted and acid extraction methods. Agric Res. (2020) 9:241-8. doi: 10.1007/s40003-019-00419-5

152. Picot-Allain MC, Ramasawmy B, Emmambux MN. Extraction, characterisation, and application of pectin from tropical and sub-tropical fruits: a review. Food Rev Int. (2020) 2020:131. doi: $10.1080 / 87559129.2020 .1733008$

153. Dranca F, Oroian M. Extraction, purification and characterization of pectin from alternative sources with potential technological applications. Food Res Int. (2018) 113:327-50. doi: 10.1016/j.foodres.2018.06.065

154. Srivastava P, Malviya R. Sources of pectin, extraction and its applications in pharmaceutical industry-an overview. Indian J Nat Prod Resour. (2011) 2:10-8. Available online at: http://hdl.handle.net/123456789/11534

155. Khan M, Nakkeeran E, Umesh-Kumar S. Potential application of pectinase in developing functional foods. Annu Rev Food Sci Technol. (2013) 4:2134. doi: 10.1146/annurev-food-030212-182525 
156. Minzanova ST, Mironov VF, Arkhipova DM, Khabibullina AV, Mironova LG, Zakirova YM, et al. Biological activity and pharmacological application of pectic polysaccharides: a review. Polymers. (2018) 10:1407. doi: 10.3390/polym 10121407

157. Ghazala I, Sayari N, Romdhane MB, Ellouz-Chaabouni S, Haddar A. Assessment of pectinase production by Bacillus mojavensis I4 using an economical substrate and its potential application in oil sesame extraction. J Food Sci Technol. (2015) 52:7710-22. doi: 10.1007/s13197-0151964-3

158. Ribeiro SAO, Nicacio AE, Zanqui AB, Biondo PBF, de Abreu-Filho BA, Visentainer JV, et al. Application of enzymes in sunflower oil extraction: antioxidant capacity and lipophilic bioactive composition. J Braz Chem Soc. (2016) 27:834-40. doi: 10.5935/0103-5053.20150335

159. Liu C, Hao L, Chen F, Yang C. Study on extraction of peanut protein and oil bodies by aqueous enzymatic extraction and characterization of protein. $J$ Chem. (2020) 2020:5148967. doi: 10.1155/2020/5148967

160. Mwaurah PW, Kumar S, Kumar N, Attkan AK, Panghal A, Singh VK, et al. Novel oil extraction technologies: process conditions, quality parameters, and optimization. Compr Rev Food Sci Food Saf. (2020) 19:320. doi: 10.1111/1541-4337.12507

161. Wong TW, Colombo G, Sonvico F. Pectin matrix as oral drug delivery vehicle for colon cancer treatment. AAPS PharmSciTech. (2011) 12:20114. doi: 10.1208/s12249-010-9564-z

162. Butte K, Momin M, Deshmukh H. Optimisation and in vivo evaluation of pectin based drug delivery system containing curcumin for colon. Int J Biomater. (2014) 2014:924278. doi: 10.1155/2014/924278

163. Liu L, Fishman ML, Hicks KB. Pectin in controlled drug delivery-a review. Cellulose. (2007) 14:15-24. doi: 10.1007/s10570-006-9095-7

164. Murata Y, Maida C, Kofuji K. Drug release profiles and disintegration properties of pectin films. Materials. (2019) 12:355. doi: 10.3390/ma12030355
165. Brouns F, Theuwissen E, Adam A, Bell M, Berger A, Mensink RP. Cholesterol-lowering properties of different pectin types in mildly hypercholesterolemic men and women. Eur J Clin Nutr. (2012) 66:591599. doi: 10.1038/ejcn.2011.208

166. Jones M, Gu X, Stebbins N, Crandall P, Ricke S, Lee SO. Effects of soybean pectin on blood glucose and insulin responses in healthy men. FASEB J. (2015) 29:596.16. doi: 10.1096/fasebj.29.1_supplement. 596.16

167. Bird K. Complex sugars from apple pectin may have anti-aging effects. CosmeticsDesign. (2011) Available online at: https://www.cosmeticsdesign. com/Article/2011/05/24/Complex-sugars-from-apple-pectin-may-haveanti-aging-effects

168. Anonymous. Find an ingredient- Pectin. Cosmeticsinfo. (2016) Available online at: https://cosmeticsinfo.org/ingredient/pectin-0

169. Kumar V, Sharma V, Singh L. Pectin from fruit peels and its uses as pharmaceutical and food grade: a descriptive review. Eur J Biomed Pharm Sci. (2018) 5:185-99. Available online at: https://www.ejbps.com/ejbps/abstract_ id/4359

Conflict of Interest: The authors declare that the research was conducted in the absence of any commercial or financial relationships that could be construed as a potential conflict of interest.

Copyright (c) 2020 Satapathy, Rout, Kerry, Thatoi and Sahoo. This is an open-access article distributed under the terms of the Creative Commons Attribution License (CC BY). The use, distribution or reproduction in other forums is permitted, provided the original author(s) and the copyright owner(s) are credited and that the original publication in this journal is cited, in accordance with accepted academic practice. No use, distribution or reproduction is permitted which does not comply with these terms. 